Benson JR, Wakefield LM, Sporn MB, Baum M and Colletta AA (1996a) Synthesis and secretion of TGF $\beta$ isoforms by primary cultures of human breast tumour fibroblasts in vitro and their modulation by tamoxifen. Br J Cancer 74 : $352-358$

Benson JR, Baum M and Colletta AA (1996b) Role of the TGF $\beta$ 's in the antioestrogen response/resistance of human breast cancer. Journal of Mammary Gland Biology and Neoplasia 1: 379-387

Butta A, Maclennon K, Flanders KC, Sacks NPM, Smith I, Mackinna A, Dowsett M, Wakefield LM, Sporn MB, Baum M and Colletta AA (1992) Induction of transforming growth factor beta in human breast cancer in vivo following tamoxifen treatment. Cancer Res 52: 4261-4264

Dalal BI, Keown PA and Greenberg AH (1993) Immunocytochemical localisation of secreted transforming growth factor $\beta 1$ to the advancing edges of primary tumours and to lymph node metastases of human mammary carcinoma. Am J Path 143: 381-389

Kong F-M, Anscher MS, Murase T, Abbott BD, Iglehart JD, Jirtle RL (1995) Elevated plasma transforming growth factor $\beta 1$ levels in breast cancer patients decrease following surgical removal of the tumour. Ann Surg 222: 155-162

MacCallum J, Keen JC, Bartlett JMS, Thompson AM, Dixon JM and Miller WR (1996) Changes in expression of transforming growth factor beta mRNA isoforms in patients undergoing tamoxifen therapy. Br J Cancer 74 : 474-478

Perry RR, Kang Y and Greaves BR (1995) Relationship between tamoxifen-induced transforming growth factor $\beta 1$ expression, cytostasis and apoptosis in human breast cancer cells. Br J Cancer 72: 1441-1446

\title{
Changes in expression of transforming growth factor beta mRNA isoforms in patients undergoing tamoxifen therapy
}

\author{
Reply to the letter from Benson and Colletta
}

\section{Sir}

The controversy surrounding the complex role of transforming growth factor (TGF- $\beta$ ) in breast cancer is once again highlighted in the letter of Mr JR Benson and Dr AA Colletta. The comments made are informative and, while we would concur with many of them, we feel that some additional response is appropriate to clarify some of the issues raised.

First of all, it is important to emphasize that the aim of our study was to determine the effect of tamoxifen on TGF- $\beta$ expression in breast cancers from patients whose tumours could be accurately assessed for response to therapy. It was not a study to elucidate the role of TGF- $\beta$ in carcinogenesis or to assess expression in different stages of disease, although we have already published data on the latter (MacCallum et al, 1994). Although the study is limited to a defined group of patients, this is an important cohort, and one in which we could obtain sequential samples of tumour and accurately assess response of these same lesions to tamoxifen treatment (Incidentally, the rationale for using ultrasound as an accurate assessment of tumour size has already been published by Forouhi et al, 1994).

Secondly, we believe we have correctly shown conservatism in terms of attributing differences between sequential samples of the same tumour to the effects of tamoxifen. It is essential that inherent variations of methodology and tumour heterogeneity are assessed and realistically taken into account. Having done this in the present study, it was reassuring that, with regard to TGF- $\beta 2$ not only was it more likely for expression to be higher in tamoxifen-treated biopsies but also that this pattern was exclusive to responding tumours. We have therefore been satisfied that these effects were mediated by tamoxifen. However, the direction of effects of treatment on TGF- $\beta 1$ were almost equally increases or decreases, and there was no statistical difference in patterns between responders and nonresponders. We have therefore been reluctant to claim dogmatically that these influences are caused by tamoxifen, despite a degree of change exceeding that of our controls.

Nevertheless, we have discussed the possibility that tamoxifen might more commonly induce the expression of TGF- $\beta 1$ in breast cancers, an effect which may not have been apparent in our study for a variety of reasons (MacCallum et al, 1996). The exhaustion of stromal induction of TGF- $\beta$, as suggested by JR Benson and AA Colletta, is also possible. However, that the stroma is the primary source of TGF- $\beta$ is controversial; both we and others have shown that TGF- $\beta$ appears to be synthesized predominantly within epithelial cells of breast cancers (Auvinen et al, 1995; MacCallum et al, 1995; Walker and Gallagher, 1995). This is not necessarily at odds with the apparent increased staining of TGF- $\beta 1$ in stroma following primary tamoxifen therapy, as reported by Butta et al (1992), if the growth factor was synthesized and secreted by epithelial cells, but sequestered by the stromal compartment. Indeed, if tamoxifen causes the death of epithelial cells, there might be an impression of upregulation in residual stroma. We would agree however, that simultaneous measurements of TGF- $\beta$ protein and mRNA would give an additional dimension to these studies. Our immunohistochemical investigations are currently under way, and preliminary data suggest that both TGF- $\beta 1$ and TGF- $\beta 2$ predominantly localize to the epithelium.

In vitro studies using cell lines and animal models have yielded important understanding of the role of TGF- $\beta$ in breast cancer, but ultimately it is necessary to look at appropriate clinical material. Such translational studies can be difficult to perform and may produce results that are subject to variable interpretation depending on perspective. However, in carrying out the reported study, we believe that we have not only generated meaningful results, but have been objective in deriving our conclusions.

\author{
$J$ MacCallum and WR Miller \\ ICRF Medical Oncology Unit, Western General Hospital \\ Edinburgh $\mathrm{EH} 42 \mathrm{XU}, \mathrm{UK}$
}

\section{REFERENCES}

Auvinen P, Lipponen P, Johanssom R and Syrjanen K (1995) Prognostic significance of TGF- 32 expression in female breast cancer. Eur J Cancer 31A: 851 
Butta A, Maclennan K, Flanders KC, Sacks NPM, Smith I, McKinna A, Dowsett M, Wakefield LM, Sporn MB, Baum M and Colletta AA (1992) Induction of transforming growth factor $\beta 1$ in human breast cancer in vivo following tamoxifen treatment. Cancer Res 52: 4261-4264

MacCallum J, Bartlett JMS, Thompson AM, Keen JC, Dixon JM and Miller WR (1994) Expression of TGF $\beta$ mRNA isoforms in breast cancer. Br J Cancer 69, 1006-1009

MacCallum J, Poulsom R, Hanby AM and Miller WR (1995) Expression and distribution of TGF $\beta$ mRNA isoforms in a small group of human breast cancers examined by in situ hybridization. The Breast 4 289-296
MacCallum J, Keen JC, Bartlett JMS, Thompson AM, Dixon JM and Miller WR (1996) Changes in expression of transforming growth factor beta mRNA isoforms in patients undergoing tamoxifen therapy. Br J Cancer 74: $474-478$

Walker RA and Gallagher B (1995) Determination of transforming growth factor beta ${ }_{1}$ mRNA expression in breast carcinomas by in situ hybridisation. J Pathol 177: $123-127$

\section{CAlendar}

\section{7-9 April 1997}

\section{Nuclear Oncology: From Genotype to Patient Care}

Thomas B. Turner Building,Baltimore, Maryland

\section{Sponsor:}

\section{Johns Hopkins University School of Medicine}

\section{Course director:}

\section{Henry N. Wagner Jr, MD}

Nuclear medicine is the medical specialty best suited to translate the exploding body of knowledge obtained from research in genetics and molecular biology into the care of patients. This fourth annual nuclear oncology conference will address how this can be done and how positron emission tomography (PET) and single photon emission tomography (SPECT) can detect the first signs of disease in patients with increased genetic risk of developing cancer. The course will include illustrative patient studies, showing how PET and SPECT can help diagnosis, staging and treatment planning and monitoring.

The Johns Hopkins University School of Medicine is accredited by the Accreditaion Council for Continuing Medical Education to sponsor continuing medical education for physicians.

The Johns Hopkins University designates this continuing medical education activity for up to 18 credit hours in Category 1 of the Physician's Recognition Award of the American Medical Association.

Fee:

Physicians: \$495; Residents, Fellows and Allied Health

Professionals: $\$ 395$

\section{Contact person:}

Program Coordinator, Johns Hopkins Medical Institutions, Office of Continuing Medical Education, Turner Building, 720 Rutland Avenue, Baltimore, Maryland 21205

Tel: (410) 9552959

Fax: (410) 9550807

Internet: rturner@som.adm.jhu.edu or Julia W. Buchanan, Course Co-director, Tel: (410) 955-8582
18-21 May 1997

\section{4th Copenhagen Workshop on Carcinoma in situ and Testicular Cancer Molecular and Endocrine Aspects Copenhagen, Denmark}

Further information from:

Dr E Rajpert-De Meyts, Department of Growth and

Reproduction, The National University Hospital, 9 Blogdamavej, 2100 Copenhagen, Denmark. Tel: +45 35455515 Fax: +45 35

456054 E-mail: erm@rh.dk

\section{7-11 September 1997}

\section{International Congress on Chronobiology \\ Paris, France}

Further information from:

Pr Yvan Touitou, Conference President, Internaitonal Congress on Chronobiology, Service de Biochimie Médicale, Faculté de Médecine Pitié-Salpêtrère, 91 boulevard de l' Hôpital, 75634 Paris Cedex 13, France. Tel: (+33-01) 40779663 Fax: (+33-01) 40779665 E-mail: touitou@ccr.jussleu.fr

\section{4-18 September 1997}

\section{The European Cancer Conference Hamburg, Germany}

Further information from:

Luc Hendrickx, Conference and Finance Manager, ECCO 9 Secretariat, FBCS - Conference Unit, Avenue E Mounier 83, B-1200 Brussels. Tel: +32 (2) 7750202 Fax: +32 (2) 7750200 